\title{
Assembling the history of the Parareptilia: phylogeny, diversification, and a new definition of the clade
}

\author{
Linda A. Tsuji* and Johannes Müller \\ Museum für Naturkunde Berlin, 10115 Berlin, Germany. E-mail: linda.tsuji@museum.hu-berlin.de
}

\begin{abstract}
Received 5 June 2008

Accepted 26 August 2008

Published 20 February 2009

\section{Key Words}

\author{
Amniota \\ Eureptilia \\ Permo-Triassic \\ evolutionary novelties \\ phylogenetic definition
}

In the present study, the historical development of Parareptilia as a phylogenetically valid clade is summarized, and for the first time a modern phylogenetic definition of both Parareptilia as well as Eureptilia is presented, which will facilitate the study of problems of early amniote classification. Furthermore, a preliminary study of the rates of diversification in parareptiles is performed on the basis of topological information on species diversity. While acknowledging that the bias of the fossil record also needs to be considered for a more definitive statement on parareptile diversification, our results show that a significant increase in diversification rate could be recorded only among Triassic procolophonoids, making it difficult to interpret evolutionary novelties such as herbivory or impedance-matching hearing as being key innovations that might have driven diversification.
\end{abstract}

\section{Introduction}

The origin and radiation of amniotes in the Late Paleozoic represents the first colonization of land by fully terrestrial vertebrates, and as such can be regarded as one of the key events in tetrapod evolution. Phylogenetically, it is widely agreed that early amniotes can be subdivided into three major clades, Synapsida Osborn, 1903, which includes mammals, Eureptilia Olson, 1947, which includes diapsid reptiles, and Parareptilia Olson, 1947, which together with Eureptilia forms the clade Reptilia Laurenti, 1768 (Reisz 1997). While synapsids and eureptiles have each received significant attention, this is not the case for parareptiles, which have, until recently, remained enigmatic and poorly studied.

Parareptilia was rarely recognized as monophyletic until the adoption of phylogenetic systematic theory by paleontologists in the 1980's. Prior to this, members of the group were scattered throughout Tetrapoda. It is now acknowledged, however, that Parareptilia is a strongly supported clade, supported in the most recent analyses by six unequivocal autapomorphies: the absence of a lacrimal-narial contact, the absence of a caniniform region, a shortened postorbital region, a single median embayment of the posterior margin of the skull roof, the absence of a supraglenoid foramen, and the absence of a subtemporal process of the jugal (see Müller \& Tsuji 2007). Outside of these unequivocal autapomorphies, the clade is distinguished by a number of other characters, including a solid prefrontal-palatine contact, a dorsally expanded quadratojugal, a large foramen on the maxilla just below the naris (anterior maxillary foramen), and a jaw articulation at the level of or slightly posterior to the occiput (Laurin \& Reisz 1995; deBraga \& Rieppel 1997).

Despite only recent recognition of the monophyly of Parareptilia, many members of the clade are well known, including the small aquatic mesosaurs, which were used to support the theory of continental drift (Du Toit 1937), and the large herbivorous pareiasaurs. Stratigraphically, the oldest known parareptiles have been recorded from Early Permian deposits, though the clade must have originated at latest in the Late Carboniferous, as clearly recognized members of the sister clade, Eureptilia, are already identifiable by this time (Reisz \& Müller 2004). Clearly by the Middle Permian parareptiles had become successful and diverse, and by the end of the Triassic members of the group had appeared in the faunas of Gondwana [e.g. South Africa (Rubidge 1995), Brazil (Cisneros et al. 2005; Cisneros \& Schultz 2003), Antarctica (Colbert \& Kitching 1975), and Australia (Bartholomai 1979)] and Laurasia [e.g. the US (Cope 1878; Reisz

\footnotetext{
* Corresponding author
} 
et al. 2002; Fraser et al. 2004), Nova Scotia (Sues \& Baird 1998), Russia (Ivakhnenko et al. 1997), Western Europe (Berman et al. 2000; Spencer \& Lee 2000; Wild 1985), and China (Gao 1983; Müller et al. 2008)]. Despite their apparent diversity and success in the Late Paleozoic, however, only one lineage, the Procolophonoidea, is known to have survived the Permo-Triassic extinction event, but even this clade had become extinct by the end of the Triassic (Modesto et al. 2003; Cisneros 2008a). As such, Parareptilia (here interpreted not to include turtles) is the only major clade of basal amniotes of which there are no extant representatives.

In the light of our increasing understanding of early amniote evolution - which has only recently reached a level that allows for broad-scale evolutionary studies beyond taxonomic descriptions - the purpose of the present paper is to provide a brief review of the history of academic research about the taxa now considered to be parareptiles as well as an update on the latest phylogenetic status of the clade. In addition, we provide a new phylogenetic definition of the clade, along with one of its sister clade Eureptilia, in accordance with the recommendations by Modesto \& Anderson (2004), and present a preliminary study on the rates of parareptile diversification.

\section{The growing understanding of parareptile phylogeny}

\section{Early classifications}

Many of the earliest references to parareptilian fossils in the literature were made in works comprised not only of descriptions, but which also involved attempts to fit these new finds into a taxonomic classification (see Owen 1860; Seeley 1888, 1892; Watson 1914a; 1914b; 1917; 1954; 1957; Goodrich 1916; Williston 1917; Broom 1924; Gregory 1946, among others). The first publication mentioning a parareptilian fossil appears to be a description of the pareiasaur Parasaurus geinitzi von Meyer, 1857, a fossil of which was first described and illustrated in 1848 (Geinitz 1848), though fossils of pareiasaurs from the South African Karoo had already been recognized but not published - by this time (Lee 1997a).

As additional fossils were described, taxa now recognized as parareptiles were often not assigned to the same group due to their high degree of morphological variation. Many tended, however, to fall within Cotylosauria Cope, 1880 , a name initially coined as a division of Theromorpha to include Diadectidae, and ironically based on a misinterpreted feature of the latter (Cope 1882). The term was soon widely adopted (Cope 1896; Case 1911; Chudinov 1957, among others), but became a 'wastebasket' term, often including a mix of what are now considered amniotes along with other anamniote tetrapods. Watson (1914a, 1914b) acknowledged that the characters holding Cotylosauria together were essentially primitive - those shared with 'stegocepha- lians' rather than shared derived characters that should be used to distinguish a group. Despite this early recognition of the limitations of this classification, however, Cotylosauria continued to be redefined and was still prevalent in the literature until quite recently.

Layered on top of the use of the term Cotylosauria was the system of classification based on the temporal fenestration in tetrapod skulls, a feature that appeared to show an evolutionary trend from the solid skull of early tetrapods to the heavily fenestrated skulls of diapsids in one lineage and synapsids in another. The terms Synapsida and Diapsida Osborn, 1903 were terms coined to classify taxa based on their patterns of temporal fenestration. Subsequently, many of the taxa now included within Parareptilia were grouped into Anapsida Williston, 1917 (those without fenestrae in the temporal region), a group that contained an amalgamation of basal amniotes and anamniote tetrapods, including turtles. Anapsida has been used variously in the literature, and is still sometimes recognized as a valid group, often as an alternative to or a subset of Parareptilia, but despite its sporadic continued use (e.g. Carroll 1988; Modesto 1999, 2000; Reisz \& Scott 2002), it is a term not favoured by current workers (Cisneros et al. 2004; Tsuji 2006). Considering the current phylogeny, this nomen implies a morphology (lack of temporal fenestration) not possessed by a number of its members including bolosaurids (Reisz et al. 2007), some nycteroleterids (Tsuji 2006), millerettids (Gow 1972), some procolophonoids (Cisneros et al. 2004), Acleistorhinus Daly, 1969 and the lanthanosuchids (deBraga \& Reisz 1996). Anapsida has also long been associated with the phylogenetic position of turtles, further complicating the meaning and definition of the term.

Olson (1947) asserted that Cotylosauria, at the time considered one of the two major lineages of 'reptiles' along with Pelycosauria (treated extensively in Romer $\&$ Price 1940), had not been subject to the same sort of taxonomic rigor. In the course of a study of diadectids, Olson (1947) found Cotylosauria to be an inadequate grouping, instead reorganizing the reptiles into two subclasses - Eureptilia and Parareptilia - the first classification to so subdivide Reptilia, and the first use of the name Parareptilia. In this original sense, Parareptilia was erected to include Chelonia and Diadecta as orders, the latter of which included seymouriamorphs, diadectids, procolophonids, and pareiasaurs. Apart from the inclusion of some non-amniote tetrapods, Olson's (1947) original diagnosis of Parareptilia is close to the modern interpretation, even recognizing that the captorhinids, despite their 'anapsid' condition, belonged to a separate lineage from that of the parareptiles. Olson's (1947) classification was largely ignored by his contemporaries, with most workers preferring to continue using and modifying Cotylosauria and Anapsida, though it should be noted that Ivakhnenko (1987) used Parareptilia in his review and classification of taxa from the Russian platform, many of which were poorly known in the west. 
Romer's famous "Osteology of the Reptiles" (1956), used a more conservative grouping than that of Olson (1947), making Anapsida a subclass of Class Reptilia, under which Cotylosauria and Chelonia are orders, with Cotylosauria containing seymouriamorphs, diadectomorphs, procolophonoids and captorhinomorphs. Other than the placement of millerettids within Lepidosauria, all of the parareptile groups known at the time were collected under the nomen Anapsida.

In the years that followed only a few comprehensive analyses of the relationships of terrestrial tetrapod taxa were completed, with the focus instead on more specific descriptive studies and rather general review papers. Kuhn (1969a) included procolophonomorphs (including procolophonids and Nyctiphruretus Efremov, 1938), along with pareiasaurs and some millerettids within the subclass Cotylosauria. Reflecting the confusion over the taxonomy of basal amniotes at the time, bolosaurids (Subclass Bolosauromorpha) and some millerosaurs (Subclass Lepidosauria) were put in a separate volume of the Handbook of Paleoherpetology containing 'miscellaneous' taxa, including placodonts, araeoscelids, and Weigeltisauria among others (Kuhn 1969b). Carroll $(1969,1982,1991)$ repeatedly suggested "Protorothyridae" [sic] to be the ancestral stock of early amniotes from which synapsids, captorhinids, mesosaurs, bolosaurs, pareiasaurs, millerettids, and procolophonids had independently evolved. Other analyses during these years began to look at more open and systematic methods of determining relationships between tetrapod taxa (Heaton 1980; Heaton \& Reisz 1986, among others) and slowly the importance of these early amniote fossils became apparent.

\section{The impact of phylogenetic systematics and the turtle debate}

In the late 1980's, a more open and objective method of phylogenetic systematics using morphological characters became established, allowing a transparent, repeatable method of determining the phylogenetic relationships between taxa. The landmark paper by Gauthier et al. (1988) redefined Amniota Haeckel, 1866 , and for the first time recognized two monophyletic clades that were sister to Synapsida within Amniota. The first of these two clades was 'Reptilia' (consisting of Captorhinidae/Testudines, Paleothyris Carroll, 1969, and Diapsida), known today as Eureptilia, and the second was what they termed "parareptiles". Gauthier et al. (1988) included only four of what are now considered to be parareptiles as terminal taxa - Pareiasauria, Millerettidae, Procolophonia and Mesosauridae (Fig. 1A), but were surprised to see these taxa group together. The authors used the informal term 'parareptile' to refer to this clade, as it had very little support and they did not believe that this grouping would hold up under further scrutiny.

After Gauthier et al. (1988), a flurry of studies beginning in the 1990's attempted to further resolve early amniote phylogeny using computerized phylogenetic methods, but the importance placed on many of these analyses and the passion with which each was debated cannot be decoupled from the debate on turtle origins.

Reisz \& Laurin (1991) were the first to suggest that turtles were more closely related to procolophonoids than to other taxa. This preliminary phylogeny was the first study to begin to focus on parareptiles. Interest in parareptiles again increased when Lee (1993a) presented a preliminary analysis that also involved members of parareptilian taxa, again with an emphasis on turtles. His analysis highlighted characters supporting a turtle-pareiasaur monophyly. Although the analysis was more extensive than that of Reisz \& Laurin (1991), the number of terminal taxa was still fairly low, including only 'nyctiphruretians', Owenetta, Barasaurus, procolophonids, Sclerosaurus, pareiasaurs and turtles, and used only 45 characters, but the analysis nonetheless resulted in the monophyly of included parareptilian taxa.

Laurin \& Reisz (1995) then published a more extensive phylogeny elaborating on their 1991 paper, and for the first time focused largely on parareptilian taxa. This analysis, including 13 terminal taxa and 124 characters, produced a monophyletic Parareptilia as a sister group within Reptilia to Eureptilia (the grouping termed Reptilia by Gauthier et al. (1988)), and again demonstrated a sister-group relationship between procolophonoids and turtles. In this study, millerettids were recovered in a basal position within Parareptilia. Mesosaurs, which had always been problematic, fell outside of the crown clade Reptilia, with the nomen 'Sauropsida' being given to this more inclusive node (Fig. 1B). Lee (1995) also published a paper that included a phylogeny expanding on his 1993 analysis, including a greater number of parareptilian taxa, though the focus lay on the more derived parareptiles, with many basal parareptiles, including bolosaurids, mesosaurs, and Eunotosaurus and the millerettids consigned to the outgroup. The analysis once again demonstrated turtles nested within pareiasaurs, a point he was to reiterate in 2001 (Lee 2001).

In 1996, however, Rieppel and deBraga published an article that showed turtles to be nested well within Eureptilia (Rieppel \& deBraga 1996), a view which was subsequently supported by molecular studies (Zardoya \& Meyer 1998; Hedges \& Poling 1999). The monophyly of Parareptilia was nonetheless retained, including nine parareptilian terminal taxa (Millerettidae, Acleistorhinus, Lanthanosuchidae, Macroleter Tverdokhlebova \& Ivakhnenko, 1984, the pareiasaurs Bradysaurus, Scutosaurus, and Anthodon, Procolophonidae, and Owenettidae) within their sampling of 33 taxa and 168 osteological characters.

In 1997, two papers were published in the same issue of the Zoological Journal of the Linnean Society, with Lee (1997b) again asserting that turtles were parareptiles, and deBraga \& Rieppel (1997) arguing for their inclusion in Eureptilia. Lee's analysis included a large number of parareptilian taxa (Nycteroleteridae, Nyctiphruretidae, Procolophonidae, Owenetta, Barasaurus, 


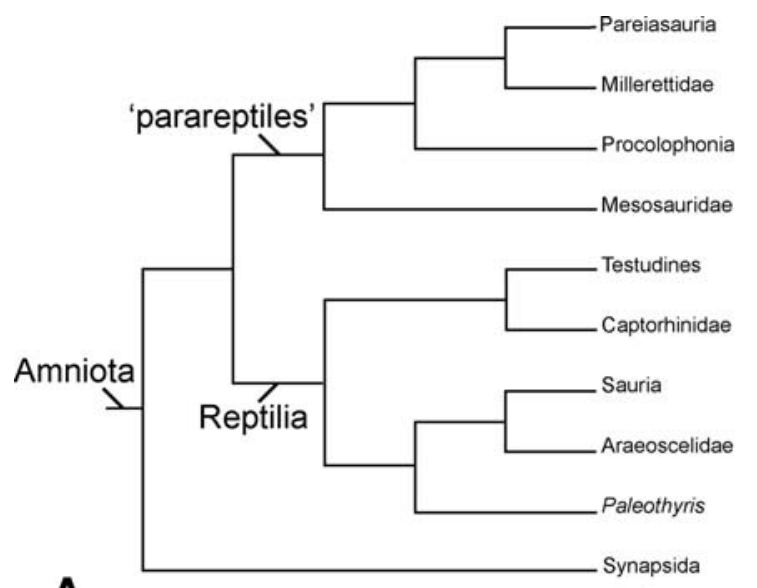

A

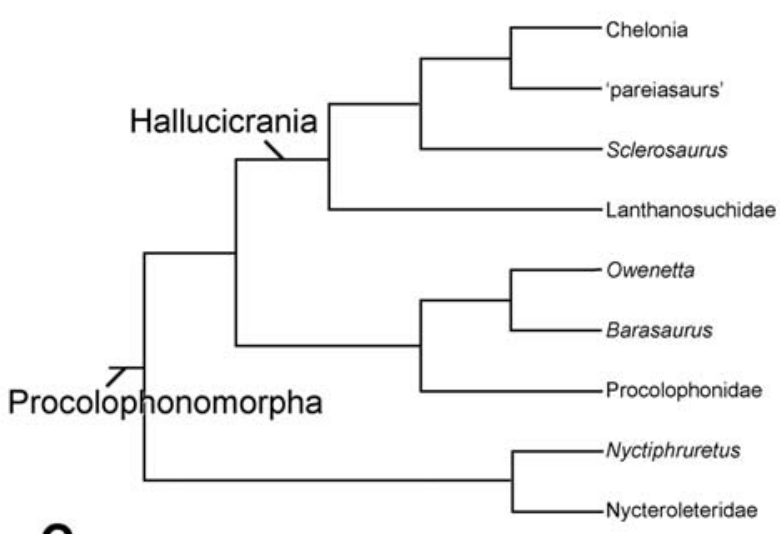

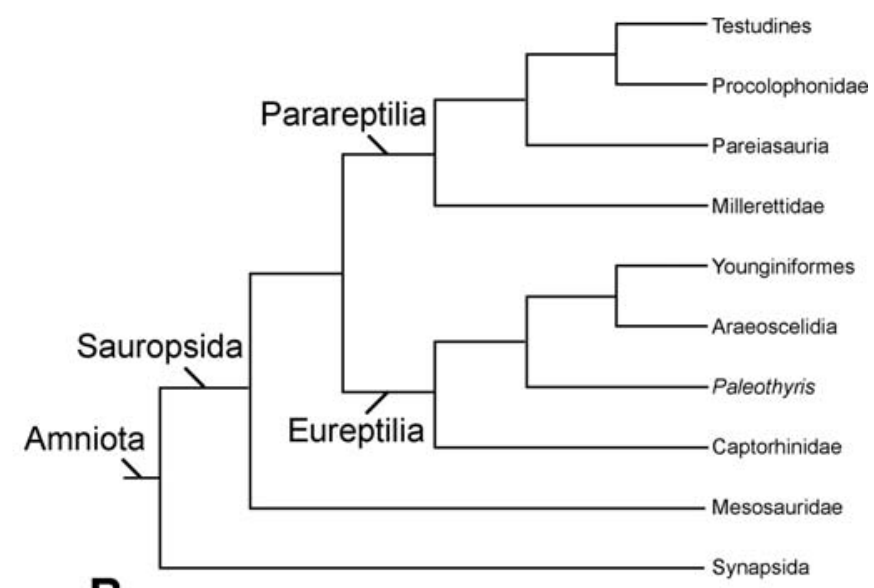

B

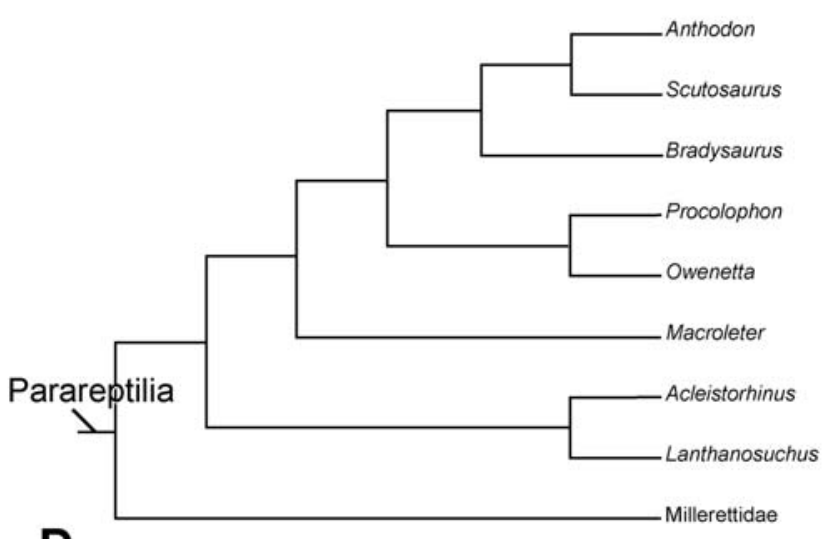

Figure 1. Phylogenetic hypotheses of parareptilian relationships. A. Redrawn from Gauthier et al. (1988); B. Redrawn from Laurin \& Reisz (1995); C. Redrawn from Lee (1997a); D. Adapted from Rieppel \& Reisz (1999).

Lanthanosuchidae, Sclerosaurus, and all known (17) pareiasaur species (and turtles)), and 128 characters (millerettids were part of a hypothetical ancestor that also included other basal amniotes) (Fig. 1C). Significantly, no individual eureptilian taxa were included in the analysis, with the monophyly of parareptiles being assumed. Lee presented a fairly detailed phylogeny of higher parareptile relationships, suggesting that Nycteroleteridae and Nyctiphruretidae form a clade that is sister to the remaining taxa, in which Owenetta, Barasaurus, and Procolophonidae are monophyletic (and termed Procolophonoidea) and sister to a clade called 'Hallucicrania', consisting of Lanthanosuchidae, Sclerosaurus, and Pareiasauridae (including turtles). The placement of the taxon Sclerosaurus has, however, been recently reevaluated (see below). DeBraga \& Rieppel (1997) countered with an elaboration of the Rieppel \& deBraga (1996) analysis (including 33 taxa, 9 of which were parareptilian and 168 characters), but also included a broader taxonomic sampling of eureptiles. While continuing to find strong support for a monophyletic Parareptilia (though with a slightly different topology than that of Lee) they again concluded that turtles fall outside this clade.

Rieppel \& Reisz (1999) reanalyzed the deBraga \& Rieppel (1997) data set incorporating Lee's (1997b) criti- cisms of some incorrect coding of characters. They again recovered a grouping of turtles outside Parareptilia, and within the latter the grouping from 1997 was also retained: Millerettidae, Acleistorhinus/Lanthanosuchidae, Macroleter, Procolophonoidea/Pareiasauria. Also, Rieppel \& Reisz (1999) thoroughly reviewed the main morphological arguments in support of a turtle-parareptile relationship - the bones making up the shell, the acromion, the astragalocalcaneal complex, and the hooked fifth metatarsal. Their arguments, which shall not be repeated here, ranged from histological to topological and even developmental aspects, showing convincingly that none of these characters fulfills the criteria of primary homology.

In the last few years there have been few continuing to support a placement of turtles within parareptiles, rather the focus shifted towards the position of turtles within Diapsida (Cao et al. 2000; Rieppel 2000; Janke et al. 2001; Zardoya \& Meyer 2001; Müller 2004; Meyer \& Zardoya 2003; Hill 2005) and how the highly modified 'anapsid' turtle skull can be derived from an ancestral diapsid condition (Müller 2003). At present the hypothesis of a turtle-parareptile relationship is no longer considered valid among the vast majority of evolutionary biologists, despite its somewhat anachronistic popularity in the paleontological community. 


\section{Recent refinement and a more detailed understanding of parareptiles}

During this period of increased interest in the phylogeny of early amniotes and large-scale analyses, an increasing number of papers appeared describing the detailed anatomy of many poorly known taxa. DeBraga \& Reisz (1996) published a redescription of the Oklahoman taxon Acleistorhinus pteroticus Daly, 1969, which was initially identified as a procolophonoid (Daly 1969). This paper also assigned the very enigmatic Russian taxon Lanthanosuchus to Parareptilia, including it in a phylogenetic analysis for the first time. The analysis again confirmed the monophyly of Parareptilia, and recognized another grouping among the more derived parareptiles called Ankyramorpha, characterized for the most part by their 'anchor-shaped' interclavicle, and comprising pareiasaurs, procolophonoids, Macroleter, and the lanthanosuchids (deBraga \& Reisz 1996).

In addition to his papers advocating that turtles were nested within pareiasaurs, Lee (1997a) also completed a much-needed reassessment of the alpha taxonomy of pareiasaurs, reducing the greatly inflated 49 species to 17, and described in detail the cranial anatomy of one taxon, Pareiasuchus nasicornis (Lee et al. 1997). Since that time, new pareiasaurs have been named from Niger (Sidor et al. 2003) and Morocco (Jalil \& Janvier 2005), greatly increasing the knowledge about this highly recognizable but previously rather muddled clade. Procolophonoids have also been the subject of renewed studies and revision in recent years, with the naming of new taxa in addition to detailed redescriptions of others, along with the inclusion of many in phylogenetic analyses for the first time (Modesto et al. 2001, 2002, 2003; deBraga 2003; Cisneros 2008a, 2008b; Cisneros et al. 2004; Säilä in press; Reisz \& Scott 2002, among others). In addition, a recent reexamination of the taxon Sclerosaurus, considered by Lee $(1995,1997 \mathrm{a})$ to be a basal member of the 'Pareiasauroidea', placed the taxon well within the Procolophonidae (Sues \& Reisz in press), confirming the suspicions of other researchers (deBraga 2003; Cisneros et al. 2005). This result better reconciles what would have been an abnormally long ghost lineage between this Triassic taxon and its exclusively Permian sister group (the pareiasaurs).

The odd-looking South African taxon Eunotosaurus had been placed within various groups within basal amniotes, including having been considered a synapsid (Lee 1993b), but a relationship to the millerettids was generally recognized (Gow 1972). Modesto (2000) was the first to include Eunotosaurus in a phylogeny, and showed that the taxon was one of the more basal taxa within Parareptilia along with Millerettidae, though the

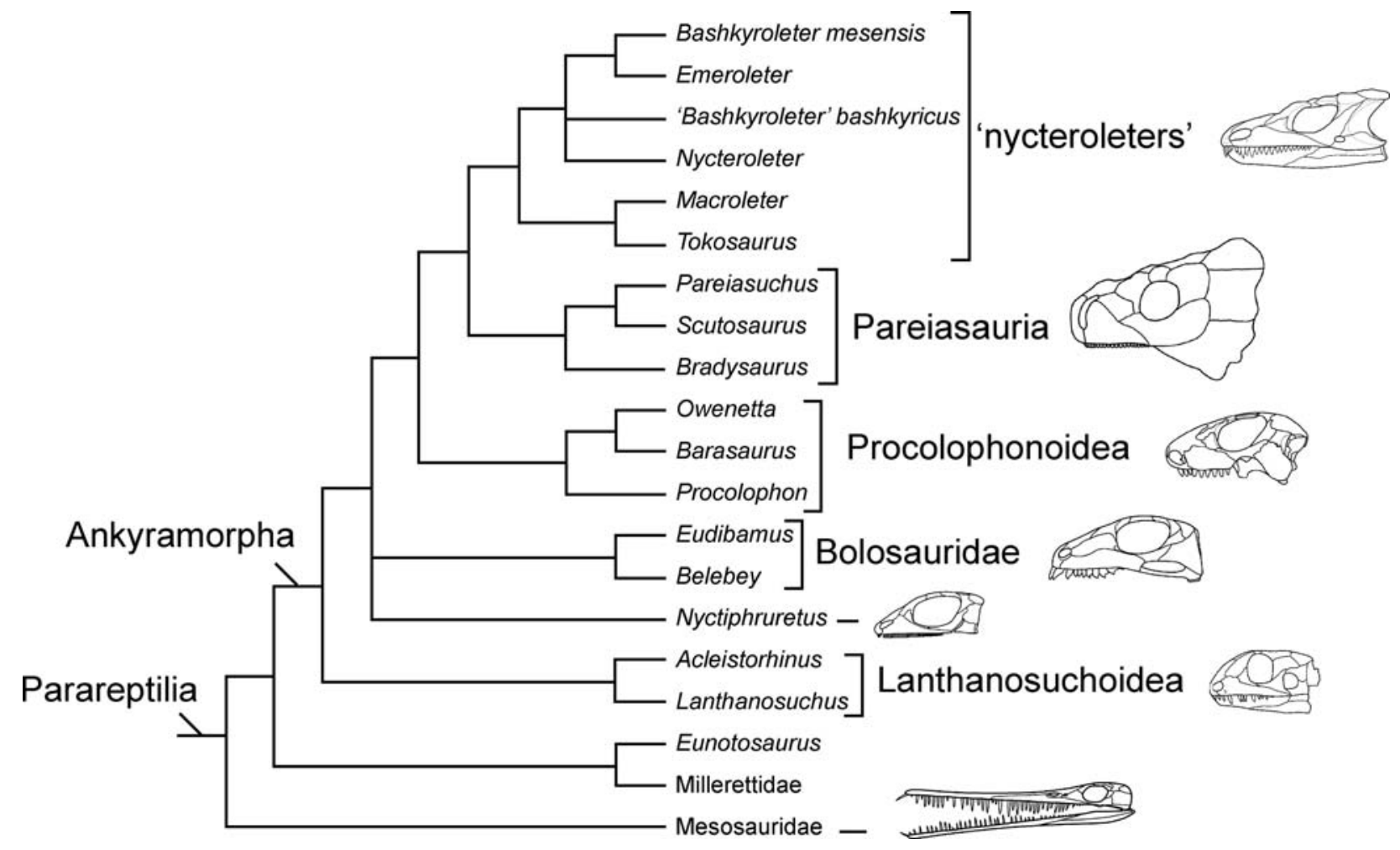

Figure 2. Most recent phylogeny of the parareptiles, redrawn from Müller \& Tsuji (2007). Skull reconstructions of (top to bottom) Macroleter poezicus Tverdokhlebova \& Ivakhnenko, 1987, modified from Tsuji (2006); Scutosaurus Hartmann-Weinberg, 1930, modified from Lee (1997a); Procolophon trigoniceps Owen, 1876, modified from deBraga (2003); Belebey vergrandis Ivakhnenko, 1973, modified from Reisz et al. (2007); Nyctiphruretus acudens Efremov, 1938, modified from Müller \& Tsuji (2007); Acleistorhinus pteroticus Daly, 1969, modified from deBraga \& Reisz (1996); and Mesosaurus tenuidens Gervais, 1865, modified from Modesto (2006). Not to scale. 
two did not fall as sister taxa in this analysis. In discussing the biogeography of the Permian and the relatively basal position of these taxa, Modesto (2000) suggested that the origin of Parareptilia was most likely to have been Gondwanan. The relationships of the closely related millerettids have also been recently reevaluated (Cisneros in press).

Another enigmatic group, the bolosaurids had long been known from Texas (Cope 1878), Russia (Ivakhnenko et al. 1997) and China (Li \& Cheng 1995), but due to the prevalence of the temporal fenestration classification scheme, they were variously considered to be synapsids (Watson 1917) or closely related to eureptilian taxa (von Huene 1956; Romer 1956). Berman et al. (2000) described a new taxon of bolosaurid from the Lower Permian of Germany, Eudibamus cursoris Berman et al., 2000. At this time, they also performed a preliminary analysis of bolosaurid relationships, based on the data sets of Modesto (2000) and Laurin \& Reisz (1995), recovering a grouping of bolosaurids well within derived parareptiles. This was the first time that bolosaurids had been shown to have parareptilian affinities. On the basis of a detailed study of the cranial anatomy of the Russian bolosaurid Belebey vegrandis Ivakhnenko, 1973 (Reisz et al. 2007), the position of bolosaurids within more derived parareptiles was further corroborated.

Mesosaurs had always been quite problematic, sometimes falling outside of Reptilia (Laurin \& Reisz 1995). Modesto $(1999,2006)$ reevaluated the position of mesosaurs within basal amniotes, adding to the matrix of Laurin \& Reisz (1995), with the result that mesosaurs fall at the base of the taxon considered to be Parareptilia, but he declined to name this clade due to controversies in the literature. Also in 2006, a redescription of the cranial anatomy of Macroleter poezicus (Tsuji 2006) included a phylogenetic analysis of parareptiles and assessed the position of this taxon based on new well-preserved fossils, in a data set also largely based on that of Laurin \& Reisz (1995). One of the main results of the analysis was a sister-group relationship between Macroleter and pareiasaurs to the exclusion of Nyctiphruretus and procolophonoids (in that order), followed consecutively by bolosaurids, Acleistorhinus/Lanthanosuchidae, Millerettidae/Eunotosaurus, and mesosaurs. The analysis of Müller \& Tsuji (2007) represents the latest overview of generalized parareptile relationships, indicating that Nyctiphruretus falls close to bolosaurids (though in an unresolved relationship) and Macroleter, together with several very similar Russian taxa previously not included in phylogenetic studies, is again most closely related to pareiasaurs to the exclusion of procolophonoids (Fig. 2).

\section{A new definition of Parareptilia - and Eureptilia}

As it can be seen, the taxonomic composition of Parareptilia along with the interrelationships among its members was at first quite fluid, but has recently be- come more stable. The definition of Parareptilia is, however, like that of Eureptilia, complicated by the uncertain placement of several key taxa, specifically the Mesosauridae, and to a lesser extent, still, turtles. Reptilia as a clade was recently defined by Modesto \& Anderson (2004) using a stem-based definition, whereas Parareptilia (deBraga \& Reisz 1996) and Eureptilia (Laurin \& Reisz 1995) are node-based. Node-based definitions, however, allow for less flexibility when phylogenetic hypotheses change, and at the same time we consider it logically more consistent when all basal nodes within Reptilia are defined equally. Thus, following the example set by Modesto \& Anderson (2004), we present here a new phylogenetic definition of Parareptilia: Parareptilia is defined as the most inclusive clade containing Milleretta rubidgei Broom, 1938 and Procolophon trigoniceps Owen, 1876 but not Captorhinus aguti Cope, 1882. In addition, Eureptilia needs to be redefined, as the definition of this group that currently stands is not compatible with modern views of early amniote phylogeny. Eureptilia has been defined by Laurin \& Reisz (1995) as "diapsids and all amniotes more closely related to them than to testudines", which does not take into account the current views on turtle relationships. We here redefine Eureptilia as the most inclusive clade containing Captorhinus aguti and Petrolacosaurus kansensis Lane, 1945 but not Procolophon trigoniceps. This type of naming - a stem-node triplet (sensu Sereno 1999), will serve to 'reinforce' the clades against changes in the placement of both mesosaurs and turtles within Amniota (as well as some other basal eureptiles with problematic positions, see Müller \& Reisz 2006), though it may be noted that mesosaurs fall within Parareptilia given the latest study of their phylogenetic position (Reisz et al. 2007). Should their phylogenetic position change and mesosaurs fall outside both Eureptilia and Parareptilia, there would be need for a new grouping within Reptilia involving only Parareptilia and Eureptilia to the exclusion of mesosaurs. By these new definitions, Parareptilia and Eureptilia can now officially be regarded as the two subclades of Reptilia.

\section{Evolutionary innovations and phylogenetic diversification}

Even though Parareptilia is the smallest of the major clades of Amniota, its members show an astonishing amount of morphological heterogeneity and evolutionary novelty. Their unique specializations range from secondary aquatic lifestyles, as seen in the middle Permian mesosaurs (Modesto 2006), to highly derived feeding mechanisms such as that of the enigmatic bolosaurids (Reisz et al. 2007), herbivory in pareiasaurs (Reisz \& Sues 2000; Lee et al. 1997), and even to novel modes of sensory perception, often predating similar evolutionary innovations in other amniotes by millions of years. 
The evolution of novel sensory perception is of particular interest as it has possibly wide-ranging evolutionary implications. It was only recently shown that the nycteroleterids from the Mezen Basin in Russia possessed a middle-ear structure that is functionally comparable to modern amniotes with impedance-matching hearing (Müller \& Tsuji 2007). The members of this clade show a lateral temporal emargination to accommodate a tympanum, a miniaturized stapes that serves as a hearing ossicle, a separation of the lateral braincase wall into foramen ovale and foramen rotundum, and the development of a lateral braincase wall separating the inner ear from the remaining parts of the brain. This is currently the only known example of an advanced auditory sense in any clade of amniotes in the Paleozoic, suggesting that novel ecological specializations had evolved in which new forms of sensory perception had become of selective advantage. While the presence of such a structure in the nycteroleterids is already remarkable in itself, the issue becomes even more interesting given the fact that at least some Triassic procolophonoids such as Procolophon and Leptopleuron also seem to possess a middle-ear structure indicative of impedance-matching hearing (Carroll \& Lindsay 1985; Spencer 2000). It currently remains unresolved if the ear of the nycteroleterids can be homologized with that of the procolophonoids, because neither Procolophon nor Leptopleuron possess a lateral braincase wall that is separated into foramen ovale and foramen rotundum, leaving doubts about the possibility of a common origin. However, if future investigations should confirm a homology between the middle ear of procolophonoids and that of nycteroleterids, impedance-matching hearing might have been one of the major evolutionary innovations among derived parareptiles, which may also include pareiasaurs, whose hearing abilities still await examination. Considering the selective advantage of such features, the question might arise if novel methods of sensory perception were driving diversification among the most derived parareptiles, which currently include the highest number of recorded species in the group.

Until now, patterns of diversification (origination minus extinction) in early amniotes have not been properly investigated. This is likely because information about the fossil record of Late Paleozoic vertebrates has not been comprehensively compiled at a level suitable for statistical evaluation, and our understanding of early amniote phylogeny only recently attained a satisfactory level (see above). As a result, it is currently impossible to make reasonable inferences about issues such as a potential relationship between amniote diversification and climate change, or if certain evolutionary novelties can be regarded as key innovations that drove diversification (see above). With regards to parareptiles, understanding their diversification patterns and potential rate shifts would be helpful to determine if the superficial increase in parareptile species richness by the Late Permian (pareiasaurs and relatives) and Trias- sic (procolophonoids) is a real phenomenon that may be attributed to certain key innovations and the P/Textinction event, respectively, or if this signal is merely the result of a biased fossil record. As a first step in the study of parareptile diversification we here present a phylogeny-based analysis, which may serve as an avenue for future in-depth investigations. We are aware that this first approximation might be strongly influenced by a bias in the fossil record or collecting, and the results should therefore be treated with caution.

For the phylogeny-based approach to investigating shifts in diversification rates we used the computer program SymmeTREE (Chan \& Moore 2004), which uses topological information about species diversity across entire trees to analyze patterns of diversification. The same program was recently used by Ruta et al. (2007) to investigate diversification shifts in temnospondyls. In contrast to Ruta et al. (2007), however, we did not use the time-slicing approach for our investigation because, as the latter authors admit, there is currently no real solution to the problem that most fossil taxa included in such a study come from different stratigraphic levels. Therefore, a conservative approach was taken using only the non-temporal cladogram topology as a reference. We used this strictly topological approach to answer the question, "Does phylogeny suggest any significant shifts in diversification rates among parareptiles?" If yes, then future research involving detailed information from the fossil record could be applied to the critical parts of the parareptile tree, and further hypothesis testing might be performed. We manually compiled a general tree of parareptile phylogeny using the study by Müller \& Tsuji (2007) as a backbone; for the more exclusive groupings, information from the following studies was used: Cisneros (2008a [procolophonoids], in press [millerettids]), Jalil \& Janvier (2005 [pareiasaurs]) Müller \& Tsuji (2007 ['nycteroleterids']), and Tsuji \& Müller (unpublished data [pareiasaurs]). Interestingly, a statistically significant shift in diversification rate (p-value $<0.05$ ) could only be detected well within Triassic procolophonoids, i.e. between 'Eumetabolodon'/Theledectes and all remaining taxa $(\mathrm{p}=0.01)$. For all other nodes, no significant diversification rate shifts could be recorded (Fig. 3). This result implies that even without correcting for the potentially biased signal from the fossil record indicating a higher diversity of parareptiles in the Late Permian, based on the current evidence there is no support for assumptions such as pareiasaurs having experienced a higher rate of diversification than other parareptiles (e.g., due to herbivory), that the middle ear of 'nycteroleterids' served as a significant key innovation, or that procolophonoids diversified at an increased rate immediately after the P/T-extinction event. On the other hand, the shift within Triassic procolophonoids deserves further attention involving more rigorous analytical approaches. Our result calls for caution when ad-hoc hypotheses are formulated relating ecological or morphological features to 


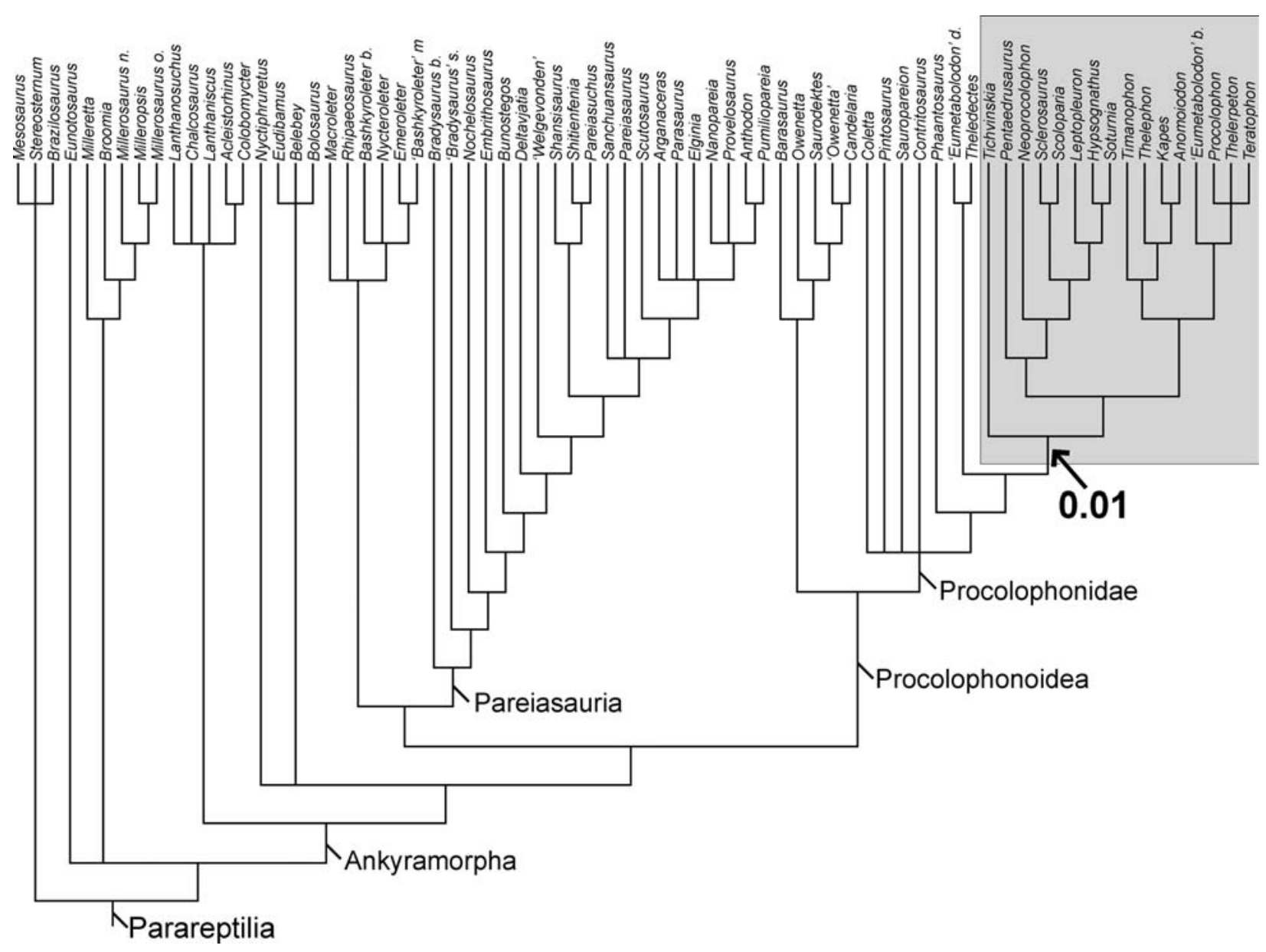

Figure 3. Compiled general tree of parareptile phylogeny with the only significant increase in diversification rate being that of the more derived procolophonids, indicated by the significant $\mathrm{p}$-value of 0.01 .

the evolutionary success of a certain clade, which is still a very common procedure in the field of paleontology.

\section{Conclusions and future research}

Despite the increased focus on parareptiles in recent years, the ingroup relationships of nearly all parareptilian clades are still poorly understood. In particular, there is a lack of fossils from Early Permian sites, and there has yet to be a parareptile found in the Carboniferous. Crucial to the resolution of the phylogeny and evolutionary patterns of parareptiles is a more detailed knowledge of the morphology of its members. For example, the plasticity of temporal fenestrations in the group calls for further study, a trait made more puzzling by its apparent stability in synapsids. Likewise, the evolutionary novelty of impedance-matching hearing warrants further investigation, with questions remaining about the potentially homologous structures seen in nycteroleters and procolophonids (see above). Another topic requiring further research is the potential effect of mosaic heterochrony in the skull of the more derived taxa, particulary with regard to the sometimes very large orbits and the very short skull table, as well as the heavy dermal ossification including bumps and spikes possessed by some members of the clade. In addition, the preliminary study of parareptile diversification presented above shows patterns that are intriguing enough to warrant more attention, whereas caution must be exerted when potential "key innovations" are correlated with diversity patterns, as they are often only adhoc hypotheses lacking reasonable support. Future studies using more rigorous statistical methods to incorporate the bias of the fossil record will provide further insights into the patterns of diversification of this group and its contemporaries.

\section{Acknowledgements}

We wish to thank Juan Cisneros for the permission to use his data on Millerettidae prior to publication. Comments by reviewers Juan Cisneros, Stuart Sumida, Sean Modesto and volume editor Florian Witzmann greatly improved the manuscript. This study was financially supported by the Deutsche Forschungsgemeinschaft (DFG Mu 1760/2-3).

\section{References}

Bartholomai, A. 1979. New lizard-like reptiles from the Early Triassic of Queensland. - Alcheringa 3: 225-234. 
Berman, D. S., Reisz, R. R., Scott, D., Henrici, A. C., Sumida, S. S. \& Martens, T. 2000. Early Permian bipedal reptile. - Science 290: 969-972.

Broom, R. 1924. On the classification of the reptiles. - Bulletin of the American Museum of Natura1 History 51: 39-65.

Broom, R. 1938. On a new type of primitive fossil reptile from the Upper Permian of South Africa. - Proceedings of the Zoological Society of London 108: 535-542.

Cao Y, Sorenson, M. D., Kumazawa, Y., Mindell, D. P. \& Hasegawa, M. 2000. Phylogenetic position of turtles among amniotes: evidence from mitochondrial and nuclear genes. - Gene 259: 139148 .

Carroll, R. L. 1969. Problems of the origin of reptiles. - Biological Reviews 44 (3): 393-431.

Carroll, R. L. 1982. Early evolution of reptiles. - Annual review of ecology and Systematics 13 (1982): 87-109.

Carroll, R. L. 1988. Vertebrate Paleontology and Evolution. Freeman, New York.

Carroll, R. L. 1991. The origin of reptiles. In Schultze, H.-P. \& Trueb, L. (eds). Origins of the Higher Groups of Tetrapods: Controversy and Consensus. Cornell University Press, New York: pp. 331353.

Carroll, R. L. \& Lindsay, W. 1985. Cranial anatomy of the primitive reptile Procolophon. - Canadian Journal of Earth Sciences 22: 1571-1587.

Case, E. C. 1911. A Revision of the Cotylosauria of North America. Carnegie Institution of Washington, Washington.

Chan, K. M. A. \& Moore, B. R. 2004. SymmeTREE: User's Guide. Software version 1.1.

Chudinov, P. K. 1957. Cotylosaurs from the Upper Permian redbeds deposits of the preurals. - Trudy Paleontologicheskogo Instituta, Akademiia Nauk SSSR 68: 19-87.

Cisneros, J. C. 2008a. Phylogenetic relationships of procolophonid parareptiles with remarks on their geological record. - Journal of Systematic Palaeontology 6 (3): 345-366.

Cisneros, J. C. 2008b. Taxonomic status of the reptile genus Procolophon from the Gondwanan Triassic. - Paleontologia Africana 43: $7-17$.

Cisneros, J. C. in press. Analysis of millerettid parareptile relationships in the light of new material of Broomia perplexa Watson, 1914, from the Permian of South Africa. - Journal of Systematic Palaeontology.

Cisneros, J. C. \& Schultz, C. L. 2003. Soturnia caliodon n. g. n. sp., a procolophonid reptile from the Upper Triassic of southern Brazil. - Neues Jahrbuch für Geologie und Paläontologie, Abhandlungen 227: 365-380.

Cisneros, J. C., Damiani, R., Schultz, C, da Rosa, A., Schwanke, C., Neto, L. W. \& Aurelio, P. L. P. 2004. A procolophonoid reptile with temporal fenestration from the Middle Triassic of Brazil. Proceedings of the Royal Society of London. Series B. 271: 1541-1546.

Cisneros, J. C., Abdala, F., \& Malabarba, M. C. 2005. Pareiasaurids from the Rio do Rasto Formation, southern Brazil: Biostratigraphic implications for Permian faunas of the Paranà Basin. Revista Brasiliera de Paleontologia 8 (1): 13-24.

Colbert, E. H. \& Kitching, J. W. 1975. The Triassic reptile Procolophon in Antarctica. - American Museum Novitates 2566: 1-23.

Cope, E. D. 1878. Descriptions of Extinct Batrachia and Reptilia from the Permian Formation of Texas. - Proceedings of the American Philosophical Society 17 (101): 505-530.

Cope, E. D. 1880. Geology and Palaeontology. - The American Naturalist 14 (4): 299-304

Cope, E. D. 1882. Third contribution to the history of the vertebrata of the Permian formation of Texas. - Proceedings of the American Philosophical Society 20: 447-474.

Cope, E. D. 1896. The reptilian order Cotylosauria. - Proceedings of the American Philosophical Society 34: 436-456.
Daly, E. 1969. A new procolophonid reptile from the Lower Permian of Oklahoma. - Journal of Paleontology 43: 676-687.

deBraga, M. 2003. The postcranial skeleton, phylogenetic position, and probable lifestyle of the Early Triassic reptile Procolophon trigoniceps. - Canadian Journal of Earth Sciences 40 (4): 527-556.

deBraga, M. \& Reisz, R. R. 1996. The Early Permian reptile Acleistorhinus pteroticus and its phylogenetic position. - Journal of Vertebrate Paleontology 16: 384-395.

deBraga, M. \& Rieppel, O. 1997. Reptile phylogeny and the interrelationships of turtles. - Zoological Journal of the Linnean Society 120 : $281-354$.

Du Toit, A. L. 1937. Our wandering continents. Oliver and Boyd, U.K., London.

Efremov, J. A. 1938. Some new Permian reptiles of the U.S.S.R. Comptes Rendus (Doklady) 19: 771-776.

Fraser, N. C., Irmis, R. B. \& Elliot, D. K. 2004. A procolophonid (Parareptilia) from the Owl Rock Member, Chinle Formation of Utah, USA. - Palaeontologia Electronica 8: 13A: 7 pp.

Gao, K. 1989. Pareiasaurs from the Upper Permian of north China. Canadian Journal of Earth Sciences 26: 1234-1240.

Gauthier, J. A., Kluge, A. G., \& Rowe, T. 1988. The early evolution of the Amniota. In Benton, M. J. (ed.). The Phylogeny and Classification of the Tetrapods, Volume 1: Amphibians, Reptiles, Birds. Systematics Association Special Volume \#35A. Clarendon, Oxford: pp. $103-155$.

Geinitz, H. B. 1848. Die Versteinerungen des deutschen Zechsteingebirges. In Geinitz, H. B. \& Gutbier, A. von (eds). Die Versteinerungen des Zechsteingebirges und Rothliegenden oder des permischen Systemes in Sachsen. Arnoldische Buchhandlung, Dresden and Leipzig: pp. 1- 26.

Gervais, P. 1865. Du Mesosaurus tenuidens, reptile fossile de 1'Afrique australe. - Comptes Rendus de 1'Academie des Sciences 60: 950-955.

Goodrich, E. S. 1916. On the Classification of the Reptilia. - Proceedings of the Royal Society of London. Series B. 89 (615): 261-276.

Gow, C. E. 1972. The osteology and relationships of the Millerettidae (Reptilia: Cotylosauria). - Journal of Zoology, London 167: 219264.

Gregory, W. K. 1946. Pareiasaurs versus placodonts as near ancestors to the turtles. - Bulletin of the American Museum of Natural History 86: 279-326.

Haeckel, E. 1866. Generelle Morphologie der Organismen. II. Allgemeine Entwicklungsgeschichte der Organismen. Georg Reimer, Berlin.

Hartmann-Weinberg, A. P. 1930. Zur Systematik der Nord-Duna-Pareiasauridae. - Paläontologische Zeitschrift 12 (1): 47-59.

Heaton, M. J. 1980. The Cotylosauria: A reconsideration of a group of archaic tetrapods. In Panchen, A. L. (ed.). The Terrestrial Environment and the Origin of Land Vertebrates. Academic Press, London: pp. 497-551.

Heaton, M. J. \& Reisz, R. R. 1986. Phylogenetic relationships of captorhinomorph reptiles. - Canadian Journal of Earth Sciences 23: 402-418.

Hedges, S. B \& Poling, L. L. 1999. A molecular phylogeny of reptiles. - Science 283 (4): 998-1001.

Huene, F. von. 1956. Paläontologie und Phylogenie der Niederen Tetrapoden. Fischer, Jena.

Hill, R. V. 2005. Integration of morphological data sets for phylogenetic analysis of Amniota: the importance of integumentary characters and increased taxonomic sampling. - Systematic Biology 54 (4): 530-547.

Ivakhnenko, M. F. 1973. New Cisuralian cotylosaurs. - Palaeontologicheskii Zhurnal 1987: 98-106.

Ivakhnenko, M. F. 1987. [Permian Parareptiles of the USSR]. - Trudy Paleontologicheskogo Instituta, Akademiia Nauk SSSR 223: 1160. [Russian] 
Ivakhnenko, M. F., Golubev, V. K., Gubin, Y. M., Kalandadze, N. N., Novikov, I. V., Sennikov, A. G. \& Rautian, A. S. 1997. [Permian and Triassic tetrapods of Eastern Europe]. GEOS, Moscow. [Russian]

Jalil, N.-E. \& Janvier, P. 2005. Les pareiasaures (Amniota, Parareptilia) du Permien supérieur du Bassin d'Argana, Maroc. - Geodiversitas 27 (1): $35-132$.

Janke, A., Erpenbeck, D., Nilsson, M. \& Arnason, U. 2001. The mitochondrial genomes of the iguana (Iguana iguana) and the caiman (Caiman crocodylus): implications for amniote phylogeny. - Proceedings of the Royal Society of London. Series B. 268: 623631.

Kuhn, O. 1969a. Handbuch der Paläoherpetologie. Part 6: Cotylosauria. VEB Gustav Fischer Verlag, Jena.

Kuhn, O. 1969b. Handbuch der Paläoherpetologie. Proganosauria, Bolosauria, Placodontia, Araeoscelidia, Trilophosauria, Weigeltisauria, Millerosauria, Rhynchocephalia, Protorosauria. VEB Gustav Fischer Verlag, Jena.

Lane, H. H. 1945. New Mid-Pennsylvanian reptiles from Kansas. Transactions of the Kansas Acadamy of Sciences 47: 381-390.

Laurenti, J. N. 1768. Classis Reptilium. Specimen medicum, exhibens synopsis Reptilium emendatum, cum experimentis circa venena et antidote Reptilium Austriacorum. Joan. Thomae, Nob. de Trattnern, Vienna.

Laurin, M. \& Reisz, R. R. 1995. A reevaluation of early amniote phylogeny. - Zoological Journal of the Linnean Society 113: 165223.

Lee, M. S. Y. 1993a. The origin of the turtle body plan: bridging a famous morphological gap. - Science 261: 1716-1720.

Lee, M. S. Y. 1993b. Eunotosaurus reinterpreted as an aberrant synapsid. - Abstracts of the Second World Congress of Herpetology: 150.

Lee, M. S. Y. 1995. Historical burden in systematics and the interrelationships of 'parareptiles'. - Biological Reviews 70: 459-547.

Lee, M. S. Y. 1997a. A taxonomic revision of pareiasaurian reptiles: implications for Permian terrestrial Palaeoecology. - Modern Geology 21: 231-298.

Lee, M. S. Y. 1997b. Pareiasaur phylogeny and the origin of turtles. Zoological Journal of the Linnean Society 120: 197-280.

Lee, M. S. Y. 2001. Molecules, morphology, and the monophyly of diapsid reptiles. - Contributions to Zoology 70 (1): 1-22.

Lee, M. S. Y., Gow, C. E. \& Kitching, J. W. 1997. Anatomy and relationships of the pareiasaur Pareiasuchus nasicornis from the Upper Permian of Zambia. - Palaeontology 40: 307-355.

Li, J.-L. \& Cheng, Z. 1995. A new Late Permian vertebrate fauna from Dashankou, Gansu with comments on Permian and Triassic vertebrate assemblage zones of China. In Sun, A. \& Wang, Y. (eds). Proceedings of the Sixth Symposium on Mesozoic Terrestrial Ecosystems and Biota. Ocean Press, Beijing: pp. 3337.

Meyer, A. \& Zardoya, R. 2003. The (molecular) phylogenetic relationships of vertebrates. - Annual Review of Ecology and Evolution 34: 311-338

Meyer, H. von. 1857. Beiträge zur näheren Kenntnis fossiler Reptilien. - Neues Jahrbuch für Mineralogie, Geologie, Paläontologie 1857: 103-104

Modesto, S. P. 1999. Observations on the structure of the Early Permian reptile Stereosternum tumidum Cope. - Palaeontologia Africana 35: 7-19.

Modesto, S. P. 2000. Eunotosaurus africanus and the Gondwanan ancestry of anapsid reptiles. - Palaeontologia Africana 36: 15-20.

Modesto, S. P. 2006. The cranial skeleton of the Early Permian aquatic reptile Mesosaurus tenuidens: implications for relationships and palaeobiology. - Zoological Journal of the Linnean Society 146 : $345-368$.

Modesto, S. P. \& Anderson, J. S. 2004. The phylogenetic definition of Reptilia. - Systematic Biology 53: 815-821.
Modesto, S. P., Sues, H.-D. \& Damiani, R. J. 2001. A new Triassic procolophonoid reptile and its implications for procolophonoid survivorship during the Permo-Triassic extinction event. - Proceedings of the Royal Society B: Biological Sciences 268 (1480): 2047-2052.

Modesto, S. P., Damiani, R. J. \& Sues, H.-D. 2002. A reappraisal of Coletta seca, a basal procolophonoid reptile from the Lower Triassic of South Africa. - Palaeontology 45 (5): 883-895.

Modesto, S. P., Damiani, R. J., Neveling, J. \& Yates, A. 2003. A new Triassic owenettid parareptile and the Mother of Mass Extinctions. - Journal of Vertebrate Paleontology 23 (3): 715-719.

Müller, J. 2003. Early loss and multiple return of the lower temporal arcade in diapsid reptiles. - Naturwissenschaften 90: 473-476.

Müller, J. 2004. The relationships among diapsid reptiles and influence of taxon selection. In Arratia, G., Wilson, M. V. H. \& Cloutier, R. (eds). Recent Advances in the Origin and Early Radiation of Vertebrates. Verlag Dr. Friedrich Pfeil, München: pp. 379-408.

Müller, J. \& Reisz, R. R. 2006. The phylogeny of early eureptiles: comparing parsimony and Bayesian approaches in the investigation of a basal fossil clade. - Systematic Biology 55: 503-511.

Müller, J. \& Tsuji, L. A. 2007. Impedance-matching hearing in Paleozoic reptiles: evidence of advanced sensory perception at an early stage of amniote evolution. - PloS ONE, 2 (9): e889.doi:10.1371/ journal.pone.0000889.

Müller, J., Li, J.-L. \& Reisz, R. R. 2008. A new bolosaurid parareptile, Belebey chengi sp. nov., from the Middle Permian of China and its paleogeographic significance. - Naturwissenschaften 95 (12): $1169-1174$.

Olson, E. C. 1947. The Family Diadectidae and its bearing on the classification of reptiles. - Fieldiana: Geology 11 (1): 1-53.

Osborn, H. F. 1903. On the primary division of the Reptilia into two sub-classes, Synapsida and Diapsida. - Science 17: 275-276.

Owen, R. 1860. On the orders of fossil and recent Reptilia, and their distribution in time. - Report of the British Association for the Advancement of Science 29: 153-166

Owen, R. 1876. Descriptive and illustrated catalogue of the fossil Reptilia of South Africa in the collection of the British Museum. British Museum (Natural History), London.

Reisz, R. R. 1997. The origin and early evolutionary history of amniotes. - Trends in Ecology \& Evolution 12 (6): 218-222.

Reisz, R. R. \& Laurin, M. 1991. Owenetta and the origin of turtles. Nature 349: 324-326.

Reisz, R. R. \& Müller, J. 2004. Molecular timescales and the fossil record: a paleontological perspective. - Trends in Genetics 20 (5): 237-241.

Reisz, R. R. \& Scott, D. 2002. Owenetta kitchingorum, sp. nov., a small parareptile (Procolophonia: Owenettidae) from the Lower Triassic of South Africa. - Journal of Vertebrate Paleontology 22: 244-256.

Reisz, R. R. \& Sues, H.-D. 2000. Herbivory in late Paleozoic and Triassic terrestrial vertebrates. In Sues, H.-D. (ed.). Evolution of Herbivory in Terrestrial Vertebrates: Perspectives from the Fossil Record. Cambridge University Press, Cambridge: pp. 9-41.

Reisz R. R., Barkas, V. \& Scott, D. 2002. A new Early Permian bolosaurid reptile from the Richards Spur Dolese Brothers Quarry, near Fort Sill, Oklahoma. - Journal of Vertebrate Paleontology 22: 23-28.

Reisz, R. R., Müller, J., Tsuji, L. A. \& Scott, D. 2007. The cranial osteology of Belebey vegrandis (Parareptilia: Bolosauridae), from the Middle Permian of Russia, and its bearing on reptilian evolution. - Zoological Journal of the Linnean Society 151: 191-214.

Rieppel, O. 2000. Turtles as diapsid reptiles. - Zoologica Scripta 29 (3): $199-212$.

Rieppel, O. \& deBraga, M. 1996. Turtles as diapsid reptiles. - Nature 384: 453-455.

Rieppel, O. \& Reisz, R. R. 1999. The origin and early evolution of turtles. - Annual Review of Ecology and Systematics 30: 1-22. 
Romer, A. S. 1956. Osteology of the Reptiles. The University of Chicago Press, Chicago.

Romer, A. S. \& Price, L. I. 1940. Review of the Pelycosauria. - Geological Society of America Special Paper 28: 1-538.

Rubidge, B. S. (ed.). 1995. Biostratigraphy of the Beaufort Group (Karoo Supergroup). Biostratigraphic Series, South African Committee for Stratigraphy.

Ruta, M., Pisani, D., Graeme, T. L. \& Benton, M. J. 2007. A supertree of Temnospondyli: cladogenetic patterns in the most species-rich group of early tetrapods. - Proceedings of the Royal Society of London. Series B. 274: 3087-3095.

Säilä, L. K. (in press). The osteology and affinities of Anomoiodon liliensterni, a procolophonid reptile from the Lower Triassic Bundsandstein of Germany. - Journal of Vertebrate Paleontology.

Seeley, H. G. 1888. Researches on the structure, organisation, and classification of the fossil Reptilia. II. On Pareiasaurus bombidens (Owen), and the significance of affinities to amphibians, reptiles and mammals. - Philosophical Transactions of the Royal Society of London 179: 59-109.

Seeley, H. G. 1892. Researches on the structure, organization, and classification of the fossil reptilia. VII. Further observations on Pareiasaurs. - Philosophical Transactions of the Royal Society of London. Series B. 183: 311-370.

Sereno, P. C. 1999. Definitions in phylogenetic taxonomy: Critique and rationale. - Systematic Biology 48: 329-351.

Sidor, C. A., Blackburn, D. C. \& Gado, B. 2003. The vertebrate fauna of the Upper Permian of Niger - II, Preliminary description of a new pareiasaur. - Palaeontologia Africana 39: 45-52.

Spencer, P. S. 2000. The braincase structure of Leptopleuron lacertinum Owen (Parareptilia: Procolophonidae). - Journal of Vertebrate Paleontology 20: 21-30.

Spencer, P. S. \& Lee, M. S. Y. 2000. A juvenile Elginia and early growth in pareiasaurs. - Journal of Paleontology 74 (6): 1191-1195.

Sues, H.-D. \& Baird, D. 1998. Procolophonidae (Amniota: Parareptilia) from the Upper Triassic Wolfville Formation of Nova Scotia, Canada. - Journal of Vertebrate Paleontology 18: 525-532.
Sues, H.-D. \& Reisz, R. R. in press. Anatomy and phylogenetic relationships of Sclerosaurus armatus (Amniota: Parareptilia) from the Buntsandtein (Triassic) of Europe. - Journal of Vertebrate Paleontology.

Tsuji, L. A. 2006. Cranial anatomy and phylogenetic affinities of the Permian parareptile Macroleter poezicus. - Journal of Vertebrate Paleontology 26 (4): 849-865.

Tverdokhlebova, G. I. \& Ivakhnenko, M. F. 1984. [Nykteroleterids from the Upper Permian of Eastern Europe]. - Paleontologicheskii Zhurnal 1984: 98-111. [Russian]

Watson, D. M. S. 1914a. On the skull of a pareiasaurian reptile and on the relationships of that type. - Journal of Zoology 1914: $155-180$.

Watson, D. M. S. 1914b. Procolophon trigoniceps, a cotylosaurian reptile from South Africa. - Proceedings of the Zoological Society of London 1914: 735-747.

Watson, D. M. S. 1917. The evolution of the tetrapod shoulder girdle and fore-limb. - Journal of Anatomy 7: 1-63.

Watson, D. M. S. 1954. On Bolosaurus and the origin and classification of reptiles. - Bulletin of the Museum of Comparative Zoology 111 (9): 299-449.

Watson, D. M. S. 1957. Early history of the sauropsid reptiles. - Philosophical Transactions of the Royal Society of London. Series B. 240 (673): 325-400.

Wild, R. 1985. Ein Schädelrest von Parasaurus geintitzi H. v. Meyer (Reptilia, Cotylosauria) aus dem Kupferschiefer (Perm) von Richelsdorf (Hessen). - Geologische Blätter für Nordost-Bayern 34/ 35: 897-920.

Williston, S. W. 1917. The phylogeny and classification of reptiles. Journal of Geology 25: 411-421.

Zardoya, R. \& Meyer, A. 1998. Complete mitochondrial genome suggests diapsid affinities of turtles. - Proceedings of the National Academy of Science 95: 14226-14231.

Zardoya, R. \& Meyer, A. 2001. The evolutionary position of turtles revised. - Naturwissenschaften 88 (5): 193-200. 